\title{
Word of Mouth Marketing Strategy by Consumer Satisfaction
}

\author{
Nurita Andriani \\ Faculty of Economics and Business, Management Department, University of Trunojoyo Madura, Indonesia \\ Email: nurita.andriani@trunojoyo.ac.id
}

\begin{abstract}
This study aims to analyze the influence of gold goods quality and service quality on WOM (Word of Mouth) by using consumer satisfaction as a variable mediator (intervening) study at Mirage Jewellery Gold Shop. The quality of gold goods is a consideration for consumers in making purchases at Mirage Jewellery Gold Shop. Respondents in this study were consumers who made transactions at Mirage Jewellery Gold Store. The analysis method used is Structural Equation Modelling (SEM) analysis that is run with AMOS program. Hypothetical test results with SEM indicate that 1 . The quality of gold goods has a positive effect on consumer satisfaction, 2 . The quality of service has a positive effect on customer satisfaction, 3. Consumer satisfaction has a positive and significant effect on WOM4.The quality of service positively influenced WOM's study on Mirage Gold Jewellery Stores.
\end{abstract}

Keywords — Product Quality; Gold Store; Service Quality; Customer Satisfaction; Word of Mouth; WOM.

\section{Introduction}

Indonesia's economy is progressing in digital technology in several business sectors. The changing progress of the digital economy is changing some business sectors from offline to online, especially in the use of money transactions that have turned into digital money as a practical means of exchange. As the economy grows, money becomes more virtual both physically and in value. But gold in the digital economy today has an unchanged value (hedging), gold is a good means of hedging when economic conditions are crisis, the greater the gold price crisis will be more valuable. To avoid economic crisis / gold inflation is still chosen by the public as an investment purchase product (Kusnandar, 2010).

According to Kusnandar (2010) gold is a solid and flexible metal compared to other precious metals. Gold is divided into two forms, first gold in the form of jewelry such as necklaces, rings, earrings, pendulum and bracelets. Both gold in the form of bars (antam). The value of gold has several advantages such as durable (durable), no expired limit, easy to cash, as a means of exchange and if the gold product is damaged is still valuable. So it is not surprising when gold products become the attraction of society from various classes middle and top.

Based on the results of the gold price chart analysis in2021issuedby goldprice.org, the price of gold in Indonesia in 2013 amounted to 16,500,000 rupiah increased in 2021 by $17,500,000$ rupiah. This amount tends to increase every year and is supported by the tax issued by the government through PMK No. 34/PMK.010/2021 that the gold to be purchased is taxed at $0.45 \%$. However, from the interview conducted by Feby Novaliusas a journalist okezone.com Friday, Nov. 6, 2021, this does not shrink consumers in purchasing gold products.

Fig.1: Gold prices in Indonesia over the past 5 years

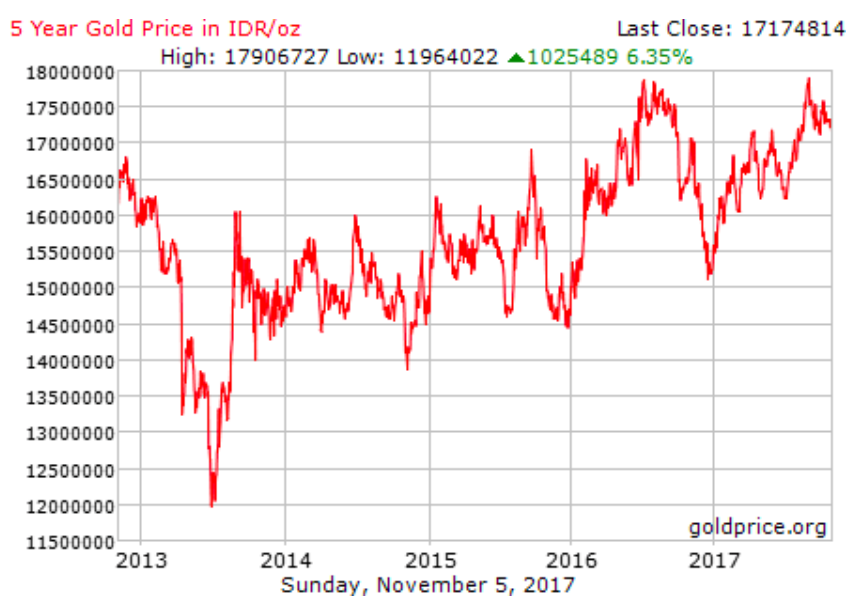

Source: Goldprice.org. (2021)

The habit of Indonesian consumers to purchase gold jewelry as a life style drove the growth of gold jewelry increasedby9-18percentin2015-2021.Gold jewelry is predicted to continue to increaseby11.8percentin2016-2021 due to market demand showing an upward trend. This is driven by two economic factors and purchasing power factors, where consumers are more interested in buying goods to the maximum to embellish the appearance and invest.

The more gold jewellery businessmen, the competition will be tighter, khususnya in the city of Surabaya which has a lot of competition gold stores. On the bps website of Surabaya City. Of course, not all surabaya residents visit the gold shop in their sub-district. Therefore, it takes a grouping of gold shop visitors to make it easier for the manager of the gold store to determine the target.

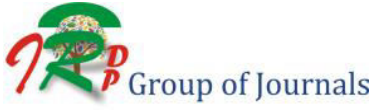


According to the Survey of 30 respondents who make purchases at gold stores mirage jewelry, in general visitors can be grouped in Table1.

Table 1. Characteristics of Gold Purchase Visitors by Age Group

\begin{tabular}{|c|l|}
\hline Age Group & Characteristics \\
\hline$<20$ years & $\begin{array}{l}\text { White gold, Light gold, Gold with luxury } \\
\text { brand models, colored gold jewelry, } \\
\text { contemporary gold models }\end{array}$ \\
\hline $21-35$ & $\begin{array}{l}\text { Gold with luxury brand model, Colored } \\
\text { gold, Antam Gold, Gold with up to date } \\
\text { model, Gold that can be exchanged } \\
\text { whereas }\end{array}$ \\
\hline $36-55$ & $\begin{array}{l}\text { It doesn't matter which model gold jewelry } \\
\text { is important and can be exchanged } \\
\text { anywhere }\end{array}$ \\
\hline
\end{tabular}

Source: Respondents Gold shop mirage jewellery, 2021

Gold store managers don't just stop at gold products. WOM is needed so that consumers know about gold stores that are suitable and comfortable to visit. WOM has an influence on consumer confidence in other consumer reviews of air recommended stores(suprapti,2010:274). But at Mirage Jewelry has some complaints from 30 respondents who have made purchases at the mass store, such as poor service, facilities inadequate etc. So that consumers are less satisfied with the services provided by the store.

Table 2. List of Consumer Complaints Mirage Jewellery

\begin{tabular}{|c|c|}
\hline $\begin{array}{l}\text { Customers } \\
\text { by age }\end{array}$ & Types of Complaints \\
\hline \multirow{3}{*}{$17-19$} & Models less up to date especially white gold \\
\hline & No hot air conditioning \\
\hline & Unique gold models and imports are just a few \\
\hline \multirow{3}{*}{$20-24$} & The service is not friendly \\
\hline & No waiting room or seating to wait \\
\hline & $\begin{array}{l}\text { New items are stored in deep stock and are not } \\
\text { issued in storefronts }\end{array}$ \\
\hline \multirow{3}{*}{$25-55$} & Jostling - urging (narrow shop) \\
\hline & $\begin{array}{l}\text { Some gold new models are stored and not } \\
\text { issued all so have to ask the storesales first }\end{array}$ \\
\hline & Less friendly service \\
\hline
\end{tabular}

Source: Consumer Questionnaire, 2021

This list of consumer complaints was obtained from a preliminary study questionnaire of 30 respondents who had made transactions at mirage Jewelry Gold stores, with an age range of 17-55years. Thisconsumercomplaint arises because consumers who make purchases in gold stores are less satisfied with the service of the mas heritage store, where it is mentioned that some consumers state that the new model gold goods are not removed from the storefront but stored oleh store owners and consumers must be active or waiting for the store sales to inform new goods. Without a good service, consumers will not be satisfied because consumers have high expectations that must be met.

Based on the background that has been delivered before, there is an increase in the number of gold stores in the city of Surabaya. This growth is very important because of its contribution to the income of Surabaya. But if businesses do not pay attention to the quality of goods, services and customer satisfaction then the age of this gold business will be rivaled by other gold stores. Through this research, it is expected that there is a good effect of the quality of goods, and the quality of service that will later increase customer satisfaction that has an impact on WOM.

Based on the business phenomenon described in the background, the increase in the number of high gold stores can lead to intense competition, as well as consumer complaints that can reduce consumer confidence that can later impact WOM negative. It takes good handling and understanding of the quality of goods and the quality of service performed to strengthen customer satisfaction. By using a research model that is not the same as previous research, the problem that will be reviewed is "how to improve the quality of goods and the quality of services to improve WOM". The purpose of this research is as follows: (1) In order to analyze the influence of the quality of goods on the tendency of consumer satisfaction in The Mirage Jewelry Gold Store; (2) To be able to analyze the influence of service quality on the tendency of customer satisfaction in Mirage Jewelry Gold Shop;(3) To be able to analyze the effect of service quality on WOM on Mirage Jewelry Gold Shop;(4) To be able to analyze the effect of customer satisfaction on WOM on Mirage Jewelry Gold Shop.

\section{Study Library - Word of Mouth}

Houshang Taghizadeh (2012) in his journal said WOM is a consumer communication about goods and services where WOM communication has a strong persuasive power. It is also explained that WOM is an application, advice and advice that has experienced the service of goods or services to others so that consumers gain trust or information on a service or goods effectively compared to the communication provided by the company.

Katz dan Lazarsfeld (2011) in his journal said that WOM is more effective than promotional media such as newspapers, TV, advertising, magazines, personal selling radio and others in influencing consumers to change brands or loyal to certain brands. Hal this shows WOM more credible where consumers tend to review a product first

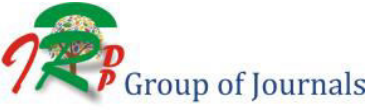


before persuasive other consumers in making purchases of a product or service driven by needs or desires. For example, a mother who makes a gold purchase transaction, at the time of making a gold purchase the store seller is very friendly and informative in serving the mother, so that the mother is satisfied, then do WOM to her community of 20people.

Based on that, dap at concluded that WOM can influence the mindset of consumers in the hope that the consumer is satisfied and give a positive disclaimer or positive response to the goods or services that have been done. However to make WOM positive it must have a quality of product or quality of service that is acceptable to consumers.

\subsection{Customer Satisfaction}

Previous researchers have said that consumer satisfaction is a process of emotional response, pure cognitive response, total psychological summary, fulfillment response or evaluation of overall purchase (Oliver, 2001 andFornell,2002). But a recent study on consumer satisfaction described a summary of affective responses that vary in intensity that focuses on product choice, purchase and consumption(GieseandCote,2000).

Customer Satisfaction has a direct influence on WOM and it is stated that when a consumer is satisfied with the service or product of a company, it will have the tendency to be loyal to the company is very high because it is driven by potential customers and positive consumers. Thus WOM is the main indicator that supports consumer satisfaction with4dimensionindicatorsnamely,(1)altruism, (2)Instrumentalism(desire to inform positive things to others, or provide intelligent information), (3) ego defenses,(4) cognitive response (Dichter2006 and Arndt2007).

\subsection{Service Quality}

Service quality is a service performance behavior that has criteria in accordance with consumer expectations that are directly related to customer satisfaction (Bolton and Drew, 2001). The quality of service is an important factor for the company especially there is a gold shop mirage jewelry so as not to compete with other gold companies. According to Davidgardin and Leod (2007) service quality has 7 dimensions namely performance, features, reliability, durability, ease of improvement, beauty and perception.

Previous research applied the SERVQUAL method, the quality of service that consumers expect is the difference between actual performance and expectations received so that gap values will be obtained from each of the different dimension attributes. (Santos Rodrigueetal, 2010). SERVQUAL is influenced by four factors, namely real, intangible (attention to consumers), efficiency of performance to the company and efficient performance to the company. With the SERVQUAL method, it is expected that the service quality can bead just wherever you are, and can avoid mistakes that exist in the company both internally and externally.

\subsection{Quality of Goods}

The quality of goods is the consumer's perception of the overall quality or excellence of goods related to the purpose that has been set relatively and alternatively(Ehsani,2015). While Kotler and Armstrong, 2012 suggests that the quality of the product is a characteristic of the product or service that suits the needs to satisfy consumers. Kotler 2012, also suggests the quality of the product has seven indicators including, aesthetics, perception of quality, service power, features, performance, reliability, and compliance. In previous research product quality is not reviewed by the company's point of view, the determination of the main product quality direction is reviewed from a consumer perspective so that the emergence of two factors of product quality that consumers expect and the quality of the product is felt in the hope that the quality of the product can lead to consumer satisfaction. For example in the store Jewelry Gold there are gold products that are yellow, but the many mindsets of the younger generation yellow = old then the gold company provides an alternative selection of gold products with colorful colors so as to create satisfactory product characteristics in consumers.

\section{Influence between Variables}

\subsection{The Effect of Gold Quality on Consumer Satisfaction}

The quality of gold goods has different characteristics of goods according to the conditions, which products are made as needed to meet consumer expectations. (Kotler, 2012). Products will be assessed as quality if in accordance with market needs such as physical goods, ideas, product usability, place, uniqueness etc. Consumers who make purchases of a quality product will definitely feel satisfied, appropriate and happy, this provides added value to the product suatu.

The quality of the appropriate products offered will have a positive impact on consumer satisfaction, in Ismail Razak's research, 2016 assumes that products that meet expectations in all aspects will directly affect consumer satisfaction. Dari definition above shows that the extent to which consumer expectations are met raises a high level of 
positive consumer satisfaction so as to create a positive relationship between the quality of gold goods and satisfaction consume.

\section{H1: There is a positive and significant Influence of Quality of goods on Consumer Satisfaction}

Effect of Service Quality on Customer Satisfaction

The quality of services that are in accordance with the wishes, consumer needs will have a positive impact on customer satisfaction, so in previous research the quality of service to customer satisfaction at private companies in Faisalabad positively and significant. The dimension of service quality according to Parasumanetal (2008)which has now been reviewed by Tariqkhalil (2013) shows the quality of service is able to compete and perceived performance exceeds consumer expectations so that in previous research in the private service sector faisalabd resulted in the hypothesis of positive and sign ifikan service quality. From previous research can be drawn hypotheses are:

\section{H2: There is a positive influence of Service Quality on consumer satisfaction}

The Effect of Consumer Satisfaction on WOM Consumer satisfaction received by individuals will certainly have a positive impact, $\mathrm{A}$ and previous research by Prevista Fakhrun Nisa stated that the influence of consumer satisfaction has a positive and significant effect on WOM on the services of bus men mass economy class, also in previous research researched by dhikaamalia about BPJS Ponorogo resulted in that consumer satisfaction encourages people to do WOM so that from the study consumer satisfaction has a positive and significant effect on WOMBPJS Ponorogo. From the above research can be described i.e.,

\section{H3: There is a positive influence of Consumer Satisfaction on WOM}

\subsection{Effect of Service Quality on WOM}

Service Quality is the key to the success of the company to win the competition, but all companies have the same thinking so that many service companies have the same quality of service, this causes the quality of service is not the key to the success of the company is the only one. (Ayu, 2011). The development of service quality is now more innovative, consumer increasingly communicative provide feedback on the quality of services provided through WOM.

Loannis E in his research "Service quality effect on satisfaction and word of mouth in the health care industry" proves that the equality of service directly affects WOM but in other dimensions emphatically gives influence to tangibles, responsiveness and assurance so that the quality of service indirectly affects WOM this creates positive results so that the influence on WOM.

\section{H4: There is a positive influence of Quality of Service on WOM.}

\section{Research Methods}

The types of data used are primary data and secondary data. Primary data is data collected directly conducted in the field in the form of attitudes, opinions, or experiences of one person or group conducted by people who conducted research. In filling out the questionnaire, respondents are directed to answer some questions such as the respondent's identity, respondent's response etc. Questionnaire answers in this study by providing an ordinal measurement scale. The scale divides the score into seven squares, where the score is one for the respondent's highly disagreed or low answer and the score of seven for the respondent's high answer.

According to the description of the library study, there are sixteen indicators that will be measured from the total of four variables. The four variables are Quality product consisting of 4 indicators of product variation, jewelry design, gold content and gold products can be accepted in other stores, Quality Service consists of 4 indicators namely good capture, accurate information, attractive appearance, friendly service, Consumer Satisfaction has 4 indicators among them according to expectations, honesty, international product quality standards, facilities and the latter is WOM variable that has 4 indicators.

Secondary data on this study was obtained in direct through journals, news, books, reports, scientific works and government agencies that have been published by certain parties. With the hope that this secondary data can be a supporter of primary data where the data emphasizes on the quality and suitability of researchers in using and selecting it.

\section{Population and Sampling}

\subsection{Population}

Population is defined as a group of individuals who share certain characteristics that distinguish groups from other individuals (Ferdinand, 2015). The entire population in this study is consumers who make transactions in gold stores mirage jewelry that is not yet known how many consumers make purchases every day.

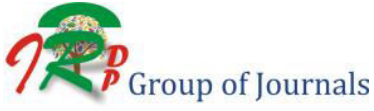




\subsection{Sampling}

The sample is a part of population that is expected to represent the population in the study (Ferdinand, 2006). Sampling method is done through nonrandom sampling method which is accidental sampling where the sample is done quickly on consumers who make purchases of gold products at mirage jewelry gold store on that day. Testing in this study using a tool that can measure causality relationships contained in causal models. In order to be eligible to use the analysis tool, the minimum sample is determined by multiplying the number of indicators.

Based on the SEM method described above, the minimum sample is 80 respondents and the maximum sample is 160 respondents, but to avoid the existence of a low response rate and ease of results in processing it is decided that a maximum sample of 160 respondents will be taken.

\section{Validity and Reliability Test}

\subsection{Validity Test Data}

Questionnaires can be said to be valid when questions in questionnaires can reveal things measured through the questionnaire itself (Ghozali, 2012). Validity tests were conducted to clarify the faithful answers of some of the variables and indicators used in the research model. This test was conducted by comparing critical ratio value with standard error. The variable indicator is declared valid if the estimated critical ratio value is $2 \mathrm{x}$ greater than its standard error value.

\subsection{Reliability Test}

The consistency of the answers given by respondents was measured. A data is called reliable if the respondent is consistent in answering the questions in the questionnaire. The reliability test is also used as a custodial test of the indicator size of a variable using cronbach's alpha coefficient formula (ghozali, 2012). Where when the result of alpha coefficient with significance level of $70 \%$ or 0.7 can be said reliable and when alpha coefficient $<$ with significance level of $70 \%$ or 0.7 can be said not reliable.

\subsection{Analytical Techniques}

Analysis of this study using Structural Equation Model (SEM). The selection of the use of this technique is based on its ability to process and test a series of relationships that exist in the research model simultaneously although relatively complicated. There are seven steps in using SEM,
- Development of theoretical models - The first step is to develop a model that is equipped with a strong theoretical basis. Then the model is empirically validated.

- Flow charting - Flow charts are used to describe causality relationships that will be tested in this study. This form of equation is commonly used to determine causal relationships. There are two groups that build flowcharts, which are as follows:

1) Exogenous Constructs (Exogenous Constructs) The construct describes a variable that other variables in the model cannot predict. Exogenous constructs are also known as "independent variables "or " source variables".

2) Endogenous Construct (Endogenous Construct) Endogenous constructs are factors predicted by one or more constructs. Through these constructs, one or more other endogenous constructs can be predicted, but only causal relationships can be struck between exogenous constructs and endogenous constructs.

\subsection{Structural Equations}

The equation is designed to give a statement on a causality relationship to various constructs. In structural equations can be arranged as follows:

Endogenous Variables $=$ Exogenous Variables + Endogenous Variables + Errors

Evaluation of goodness criteria-of-fit- Testing of suitability on models through goodness of fit criteria is conducted at this stage. Some conformity indexes and cut off values used to test a model that has been submitted can be accepted or rejected.

- Evaluate whether SEM assumptions have been fulfilled, namely: size, sample, normality, linearity outliers and multi-co linearity and similarity.

- Conduct conformity tests as follows:

1) $X^{2}$ Chi-Square Statistics - The model tested received if its chi square value a little. The fewer squared $x$ values the better the model used and accepted according to profitability with $\mathrm{p}$ greater than 0.05 or $\mathrm{p}$ greater than 0.10 .

2) RMSEA (The Root Mean Square Error of Approximation) - RMSEA is a Goodness-of-Fit value that can be expected when the model is estimated in the population. If the RMSEA value $\leq$ 0.08 then the model is acceptable.

3) GFI (Goodness-of-Fit Index) - GFI is a non statistic size that has a value range of 0.0 (poor fit) to 1.0 (perfect fit).The high value in this index indicates a "better fit"

4) AGFI (Adjust Goodness-of-Fit Index) - AGFI can be recommended when the Adjust Goodness of fit

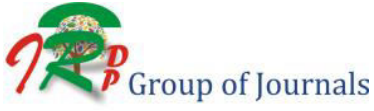


Index has a value of $\geq 0.90$.

5) $C M I N / D F$ (The Minimum Sample Discrepancy Function) - CMIN/DF shows the result of dividing chi square with df so that it is called relative square $\mathrm{x}$. The relative $\mathrm{x}$ squared value received is $\leq 2.0$ or 3.0 , so it is an indication that comes from acceptable fit between the model and the data.

6) TLI (Tucker Lewis Index) - TLI shows an alternative comparison number of a model tested with a baseline model. The TLI result received from a model is $\geq 0.95$ indicatesbetterfit.

7) CFI (Comparative Fit Index) - The CFI value is $\geq 0.95$ indicates a conformity result that is not affected by the number of samples. If the CFI value is getting closer to one then the model is getting better or showing better fit.
Table 3. Equations in Research

\begin{tabular}{|c|c|}
\hline & nous Constructs \\
\hline $\begin{array}{l}\text { X1.1= 영 1Quality Of } \\
\text { Goods +d1 } \\
\text { X1.2=2Quality of Goods }+ \\
\text { d2 } \\
\text { X1.3=영 3Quality of } \\
\text { Goods + d3 } \\
\text { X1.4 =4Quality Bcharcoal } \\
+\mathrm{d} 4 \\
\text { X2.1 =5 Service Quality +d } \\
5 \\
\text { X2.2=6 Service Quality }+ \text { d6 } \\
\text { X2.3 =7Service Quality }+ \text { d7 } \\
\text { X2.4 =8Service Quality }+ \text { d8 }\end{array}$ & $\begin{array}{l}\text { Y1.1 = 9 Customer Satisfaction } \\
\text { +e9Y1.2=10 Customer } \\
\text { Satisfaction + e10 } \\
\text { Y1.3 = 영 } 12 \text { Customer } \\
\text { Satisfaction+e12 } \\
\text { Y1.4 = 영 } 13 \text { Customer } \\
\text { Satisfaction+e13 } \\
\text { Y2.1 = } \\
\text { 영 } 14 \mathrm{WOM+e14Y2.2=영} 15 \mathrm{~W}\end{array}$ \\
\hline
\end{tabular}

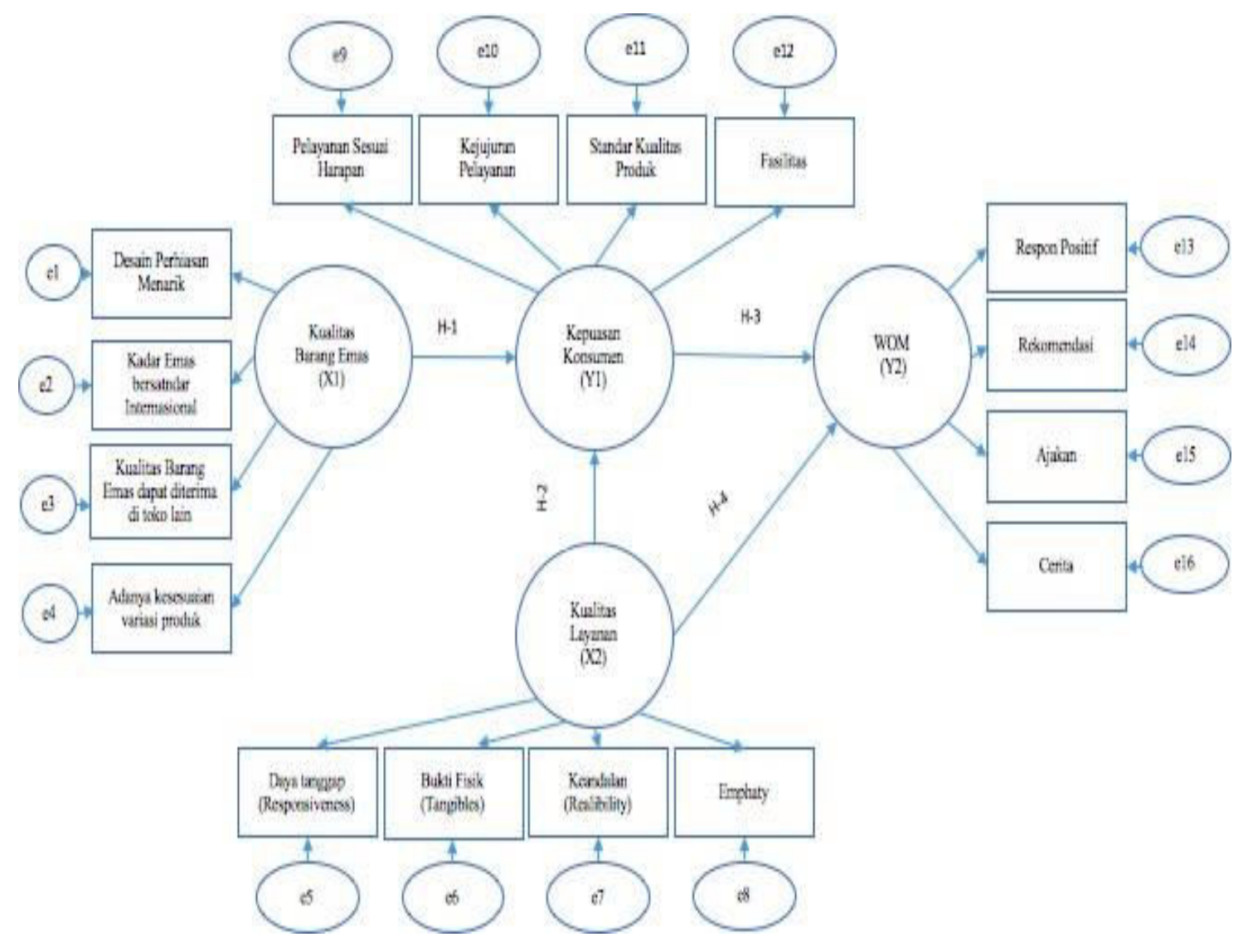

Fig.2: Research Model Flow chart

- Interpretation and modification of models Interpretation is done by looking at the test results. An estimated model is said to be good when the residual is little or close to 0 and the residual covariance distribution is symmetrical. Statistically the limit on values at the $5 \%$ rate allowed for the UK is interpreted as statistically significant at 1.96 .

\section{Results and Discussions}

\subsection{Respondent Overview}

Respondents by Gender - The gender picture chart can be seen by 30 male respondents with a presentation of $20 \%$ and female respondents who dominated numbered 125 
people with a percentage of $80 \%$ of the total155 respondents. Based on the table, respondents were dominated by the eves. This happens because the majorities who do transactions at the Mirage Jewelry Gold Store visitors are women. Respondents in this research are visitors of the Mirage Jewelry Gold Shop.

Table 4. Respondents by Gender

\begin{tabular}{|l|c|c|}
\hline \multicolumn{1}{|c|}{ Gender } & Frequency & Percentage \\
\hline Men & 30 & 0.20 \\
\hline Women & 125 & 0.80 \\
\hline Amount & 155 & 100 \\
\hline
\end{tabular}

Source: Data Processed, 2021

Respondents by Age -The description of respondents based on the age that has been recorded in the questionnaire filling, it can be seen that respondents with the age range of $22-27$ yearswith a percentage of $62.5 \%$ of the total 155 respondents.

Table 5. Respondents by Age Type

\begin{tabular}{|l|l|l|}
\hline \multicolumn{1}{|c|}{ Age } & \multicolumn{1}{|c|}{$\begin{array}{c}\text { Number of } \\
\text { Respondents }\end{array}$} & \multicolumn{1}{|c|}{ Percentage } \\
\hline$<21$ & 11 & 7 \\
\hline $21-27$ & 97 & 62.5 \\
\hline $27-35$ & 41 & 26.4 \\
\hline$>35$ & 6 & 4.1 \\
\hline Amount & 155 & 100 \\
\hline
\end{tabular}

Source: Data Processed, 2021

Respondents by Education Level - The description of respondents based on the level of education will be displayed in the following table, where it is known that the most respondents came from high school education level as much as $83.23 \%$ amounted to 129 people and the lowest position at the figure of $1.31 \%$ is tiered D3.

Table 6. Respondents by Education Level

\begin{tabular}{|l|c|c|}
\hline $\begin{array}{c}\text { Last } \\
\text { Education }\end{array}$ & $\begin{array}{c}\text { Number of } \\
\text { Respondents }\end{array}$ & Percentage \\
\hline Junior & 7 & 4.5 \\
\hline Sma & 129 & 83.23 \\
\hline S1 & 14 & 9.03 \\
\hline S2 & 3 & 1.93 \\
\hline D3 & 2 & 1.31 \\
\hline Amount & 155 & 100 \\
\hline
\end{tabular}

Source: Data Processed, 2021
Respondents by Frequency of Visits - The description of respondents based on the frequency of visits to Mirage Jewellery Gold Shop within a month will be displayed in the table of frequency of visits, it is known that the majority of respondents visited mirage jewellery gold stores as much as $1 \mathrm{x}$ and 4 to $8 \mathrm{x}$ within a month by $32.9 \%$ and $25.8 \%$ of the total 155 respondents.

Table 7. Respondents by Frequency of Visits

\begin{tabular}{|l|c|c|}
\hline $\begin{array}{c}\text { Frequency of } \\
\text { Visits }\end{array}$ & Frequency & Percentage \\
\hline $1 \mathrm{x}$ & 51 & 32.9 \\
\hline $1-4 \mathrm{x}$ & 34 & 21.9 \\
\hline $4-8 \mathrm{x}$ & 40 & 25.8 \\
\hline$>10 \mathrm{x}$ & 30 & 19.4 \\
\hline Amount & 155 & 100 \\
\hline
\end{tabular}

Source: Data Processed, 2021

Validity and Reliability Test - Based on the results of validity testing using correlate bivariate is said to be valid if each variable and its indicator shows a valuegreaterthan0.4.Questionnaire data is said to be validity when the value is greater than 0.4 of each variable and its indicator, this is indicated from the Pearson correlation value. Reliability testing on each variable and its formation indicators shows that each variable and its indicators have a reliable size. This is because Cronbach alpha $>0,6$. Then it can be said that the questionnaire is still worth using.

\subsection{Structural Equation Modelling Analysis}

Based on sem test results, obtained R Square value of 0.64 ,whereword of mouth is influenced by consumer satisfaction, quality of gold goods, service quality of $64 \%$ remaining $36 \%$ influenced by other variables that are not tested. The hypothetical model on this nelitian is in accordance with the data or fit based on the results of the examination, as in table 8.

Table 8. Structural Equation Model (SEM) Feasibility Test Results

\begin{tabular}{|l|l|l|l|}
\hline $\begin{array}{l}\text { Goodness } \\
\text { of Fit Index }\end{array}$ & $\begin{array}{l}\text { Cut-off } \\
\text { Value }\end{array}$ & $\begin{array}{l}\text { Analysis } \\
\text { Results }\end{array}$ & $\begin{array}{l}\text { Model } \\
\text { Evaluation }\end{array}$ \\
\hline Chi-Square & $<162,738$ & 102,784 & Good \\
\hline Probability & $\geq 0.05$ & 0,377 & Good \\
\hline RMSEA & $\leq 0.08$ & 0,016 & Good \\
\hline Gfi & $\geq 0.90$ & 0,922 & Good \\
\hline AGFI & $\geq 0.90$ & 0,893 & Marginal \\
\hline TLI & $\geq 0.95$ & 0,967 & Good \\
\hline Cfi & $\geq 0.95$ & 0,996 & Good \\
\hline
\end{tabular}




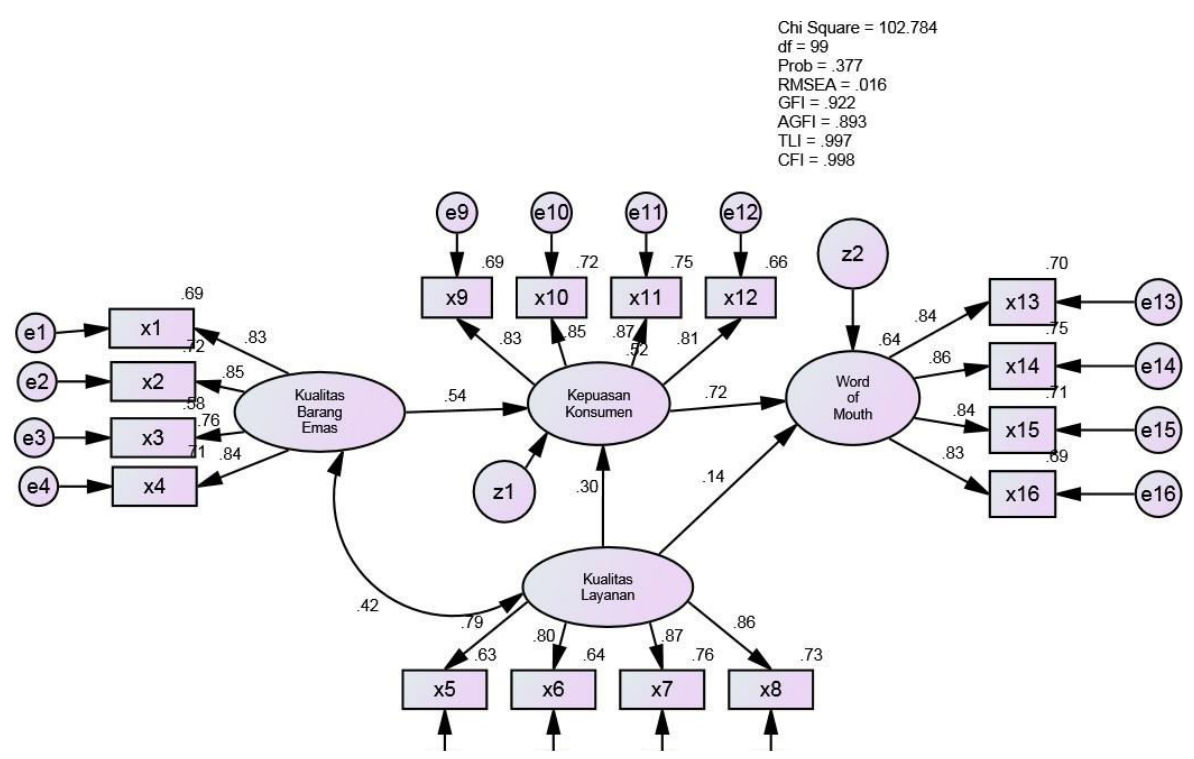

Fig.3: Structural Equation Model (SEM) Test Results

Based on Table 8, it is mentioned that the value of chi square feasibility of SEM model is good, where the value of chisquareis102,784 which is smaller than chi square table 162,738.Butat AGFIvalueof0.893which is smaller than the standard value more than 0.90 with marginal model value. It can be said that the variable used is not in accordance with the recommendations, but the value is close to the recommendation so that the evaluation of the model is still feasible continued (Hairetal, 2008). In order to provide answers to the proposed hypothesis, a statistic test is required on the relationship between variables that will be used as a basis. The SEM model can also describe the significance of the relationship between variables with probability (p) and Critical Ratio (CR) values so that more details can be seen in the following table.

\section{Conclusion and Implication}

The data analysis that has been done has 4 hypothetical conclusions, among others: (1) the results of the H1studyfound a positive influence between the quality of gold bars to consumer satisfaction, it can be said that the higher the quality of gold will increase customer satisfaction Mirage Jewelry Gold Shop. On the subject of research gold stores heirloom each indicator is able to present the quality of gold goods that can satisfy consumers such as attractive jewelry, the existence of international certification and others so as to lure consumers to visit the store more than once; (2) H2 hypothesis accepted, because of the quality of service that positively affects customer satisfaction by respondents, the good quality of service from gold shop mirage jewelry can increase the superiority of consumer satisfaction; (3) The H3 hypothesis is found to have a positive influence between consumer satisfaction and WOM. The higher customer satisfaction will help improve WOM Mirage Jewelry where it is done by gold shop consumers who are satisfied. Thus the H3 hypothesis is accepted; (4) Hypothesis regarding the quality of service that directly affects WOM shows positive results, so it can be said that the higher quality of service will help consumers in doing WOM, thus the H4 hypothesis is accepted.

\subsection{Research Limitations}

The limitations of research that can be drawn from this research are as follows:

(1) The variables studied are only 3 types of variables that affect WOM namely The Quality of Gold Goods, the quality of service and customer satisfaction; (2)The results of this study cannot be generalized in other cases outside the object of this study, namely: Mirage jewelry gold shop;(3)Limitations of researchers to reach other gold stores in Surabaya.

\subsection{Suggestion}

The upcoming research agenda is as follows: (1) Provide additional independent variables that can affect WOM; (2) Researchers can compare with other gold stores located in Surabaya so that not only focused one gold shop only.

\section{References}

[1] Ammari, N. (2012). TheEffects of Loyalty Program Qualityon Word-of-Mouth Recommendations Intentions. World Academy of Science, Engineering and Technology,64(4), 2012. 
[2] Anderson, E. W. (2008). Customer Satisfaction and WOM.Service Research, 1(1), 5-17.

[3] Anita. (2015). Comparative Analysis of Gold Precious Metals Investments with Shares of Mining Companies on the Indonesia Stock Exchange 2010-2014, 5(2), 243-252.

[4] Asteria, D. K. (2018). Jewelry Rings Become Young People's Choice. Retrieved from https://lifestyle.bisnis.com /read/ 20180417/104/785535/perhiasan-

[5] Athiyah, L.(2016).Product's Quality and Its Impact on Customer Satisfaction Afield study in Diwaniyah Dairy Factory. Proceedings of the 10th International Management Conference,57-65.Retrieved fromF/1_7.pdf

[6] Bahri- ammari, N. (2012). Effect of Loyalty Quality On Word Program - Recommendations -Mouthintentions, 6(1), 619-628.

[7] Bharwana, T. K., \& Mohsin, M. (2013).Impact of Service Quality on Customers' Satisfaction: A Study from Service Sector especially Private Colleges of .International Journal of Scientific and Research Publications, 3 (5), 1-7. https://doi.org/10.1016/ j.geoderma. 2012.02.011

[8] Chaniotakis, I. E., \& Lymperopoulos, C. (2009). Service quality effecton satisfaction and word of mouth in the health care industry. Managing Service Quality,19(2), 229-242. https://doi.org/ 10.1108/09604520910943206

[9] Febrian, A. (2018). Gold Bars Sell Sweet, How Gold Jewelry? Kontan. Co.Id. Retrieved from https://lifestyle.kontan co.id/news/emas- bars-bestselling-sweet-how- demand-gold-jewelry

[10] Ferdinand, A. (2013). Management Research Method. Semcharcoal: The Publishing Body of Diponegoro University.

[11] Imam, G. (2013).Multivariate Analysis Application with SPSS Program. Semarang: Diponegoro University Publishing Board.

[12] Kotler, P. (2009).Marketing Management. (Erlangga, Ed.).jakarta.

[13] Kusnandar, R. (2010). CFig Smart Gardening Gold.jakarta: Trans Media Library.

[14] Leonnard, S.,Comm, M., \& Thung, F. (2021). The relationship of service quality, word-of-mouth, and repurchase intention in online transportation services. Journal of Process Management. New
Technologies,5(4), 30-40. https://doi.org/10.5937/jouproman515210

[15] Muhammad Awan, H., Shahzad Bukhari, K., \& Iqbal, A. (2011). Service quality and customer satisfaction in the banking sector: A comparative study of conventional and Islamic banks in Pakistan. Journal of Islamic Marketing, 2 (3), 203-224, https://doi.org/ $10.1108 / 17590831111164750$

[16] Muhammad Tahir Jan, Kalthom Abdullah:,\& Ali Shafiq. (2013). The Impact of Customer Satisfaction on Word-of-Mouth. International Journal of Information Technology \& Computer Science, 10(3), 10.

[17] Mulyanto. (2021). The Influenceof Product Quality, Service Quality and Trust on Customer Satisfaction and Its Impact on Customer Loyalty (Case Study PT ABCTbk).International Journal of Scientific \& Engineering Research,8(7), 2330-2336.

[18] Ngo, M. V., \&Nguyen,H. H. (2016). The Relationship between Service Quality, Customer Satisfaction and Customer Loyalty: An Investigation in Vietnamese Retail Banking Sector. Journal of Competitiveness,

$$
8(2), \quad 103-116 .
$$
https://doi.org/10.7441/joc.2016.02.08

[19] Novalius, F. (2021). Buy Taxable Gold, Antam Sales Do Not Fall. Okezone.Com Retrieved from https://economy. okezone.com/ read/2021 /10/06/320/1789885/beli-emas-kena- tax-antam-callsales-not-down

[20] Service, H. K., \& Purchased, D. A. N. (2021). Relationship quality service, said- ofmouth, and purchased kembali intention in online transportation services,5(4), 30-40.

[21] Product, K.,Impact,D. A. N.,\& Satisfaction,T. (2016). Study of the importance of Research Assumptions There is a link with statistical indications between product quality and external customer satisfaction there is a relationship, 57-65.

[22] Taghizadeh, H.,Taghipourian,M. J., \&Khazaei,A. (2013). The effect of customer satisfaction on word of mouth communication. Research Journal of Applied Sciences, Engineering and Technology, 5(8), 2569-2575. https://doi.org/10.19026/rjaset.5.4698 